\title{
The Maturity of Stupidity: A Philosophical Attempt on Flaubert and Others
}

\author{
Nicolas de Warren \\ Department of Philosophy \\ The Pennsylvania State University \\ njd15@psu.edu
}

Received 29 January 2018; accepted 10 May 2018; published 30 September 2018.

\begin{abstract}
Although it is commonly held that good sense is the most equally distributed of all things, it is just as commonly acknowledged that we humans excel at stupidity in its boundless varieties. The aim of these reflections is to make a start with a philosophical examination of stupidity, combining both literature, myth, and philosophy. Rather than propose a "theory" or "concept" of stupidity, this exploration charts the archipelago of stupidity in both its wisdom and folly.
\end{abstract}

Keywords: Flaubert; rationality; stupidity.

Nous ne souffrons que d'une chose: la bêtise.

(Flaubert)

\section{Enter Stupidity}

Although it is commonly held that good sense is the most equally distributed of all things in the world, it is just as commonly acknowledged that we excel at that particular talent for misconception, wrong-headedness, and self-deceit called stupidity. Not a day goes by when we are not confronted by the human aptitude for stupidity, whether in others or in ourselves, whether individually or collectively, whether as comedic foolishness or tragic imbecility. Stupidity often manifests itself in angular ways, trumping us by surprise from unseen lines of approach; conversely, there can be something immediately reassuring about those little stupid sayings and doings which become stitched into the fabric of everyday life. How stupid I have been, we often say to ourselves in embarrassment, only to 
know that we shall repeat our signature gaffes on the morrow. And how that silly little thing which she does gives her all the magic in the world, until that day when we come to find that silly charm of hers all the more gratingly idiotic given the icy memory of love gone by. From the obscene to the loveable, stupidity, in endlessly prolific and inventive manifestations, seems to be everywhere and yet nowhere, speaking as much for as well as against humanity.

The aim of these reflections on certain salient aspects of stupidity are offered in the spirit of making a start with redressing the conspicuous silence of philosophy (with rare exceptions) regarding the pervasive and plastic phenomenon of stupidity. As Deleuze notes, philosophy's engrained obliviousness towards stupidity stems from a mutually reinforcing prejudice and conceit. The prejudice is to assume that stupidity can be reduced to forms of error and ignorance, and thus, that stupidity must always stand judged against a representation and regime of truth. There is no truth in stupidity. The conceit is to presume that philosophical discourse is the privileged site for the representation and regime of truth. There is no truth without the testimony of philosophy. This image of thought is fashioned in a spirit of seriousness. Yet, in taking itself too seriously in its claim on truth, as Aristophanes already portrayed in The Clouds, philosophy becomes both powerless when confronted with stupidity and unmasked as its own pretensions. The stupidity of philosophy resides with not taking stupidity seriously enough; it is an effort that would critically require that philosophy not take itself all too seriously. While philosophy has failed to take up stupidity, as Deleuze (1968, p. 151) writes, "with its own means and with the necessary modesty," the best of literature has been "haunted by the problem of stupidity." Such literature, as he suggests, "was able to carry it [the problem of stupidity] as far as the entrance to philosophy itself."

How might we take in the direction of stupidity a first step into philosophy? How might we carry stupidity into philosophy as its concern? An initial caution would seem to amount to an impeachment of philosophy's prized rigor. If, as Flaubert writes in a letter to his friend Louis Bouilhet (Flaubert, 1973, p. 676), "la bêtise consiste a vouloir conclure," then a philosophical venture into the problem of stupidity would have to resemble a kind of ambling into an uncharted territory without the protective armor of "definitions" and "theories," and "concepts." Does this need to conclude underwrite not the imperative of finding definitions, theories, and concepts in order to attain the seriousness of philosophy, for philosophy to speak seriously? Any attempt to find (indeed: to want to find) a definition, theory, or concept for stupidity would, on Flaubert's terms, immediately quality as imminently stupid. As Musil (1990, p. 270) admits without embarrassment in his lecture Über Dummheit: "So when confronted with stupidity I would rather confess my Achilles' heel right away: I don't know what it is." A philosophical attempt with stupidity would thus have to be eminently descriptive and sinuous. It would have to create a space of thinking not framed and stabilized by those ponderous words "definition," "theory," and "concept." It would nonetheless seek intelligibility, but on terms prescribed by stupidity itself. Philosophical thinking would have to become less exact and therefore all the more exacting of itself. 
That we-we? That I even have to begin with such a justification of this modest proposal betrays the depths to which the seriousness of philosophy shackles its writing. Sanctioned forms of philosophical writing give notice that "here genuine philosophy is seriously happening" as opposed to some other kind of discourse. Would a treatment of stupidity in philosophy not exact from philosophy an alternative form of writing, where lines of demarcation between academic and non-academic genres would necessarily become over-written while reminding mindful to avoid ostentatious over-writing which has tempted certain enterprising philosophers in writing about stupidity? And yet why must philosophers continually fret about their chosen mode of discourse - their defining neurosis - rather than fearlessly jump into the things themselves, fully embracing the risk of stupidity?

\section{The Gods Themselves}

In its most glaring manifestation, we stand dumbfounded and uncomprehending, verging on the precipice of disbelief, in the presence of stupidity. Although there can be a certain gift for stupidity in a person's startling misfire of judgment, whatever it is that painfully (for us, never for the stupid) seems to be lacking in the person who is stupid, acts stupidly, or says stupid things defies imagination as much as it humbles intelligence. We seem to be peering into an abyss - has there even been a theory or explanation of stupidity, scientific or otherwise, that would neither reduce the plasticity of stupidity to a single substance (and hence remain dumb to stupidity's manifold richness) or proclaim something utterly banal about stupidity (and hence remain idiotic in its theorizing)? Dim-witted, foolish, moronic, harebrained, asinine, doltish; dumb as a doornail, thick as a brick, not the sharpest tool in the shed... The list of terms and idiomatic expressions for stupidity is seemingly endless and ever changing. A scholarly German study "Die Ausdrücke zur Bezeichnung der Dummheit im Französischen" has collected a stupefying total of more 1,500 words, designations, metaphors (Heins, 1957). And one industrious Google Group collector has compiled a 4.7 Megabyte data-file of English expressions for stupidity, which, stupidly, cannot easily be emailed given its unwieldy massiveness (Alfvaen, 1992).

Stupidity's obscurity is often proportional to its sheer flagrancy. Stupidity strikes us without any residual ambiguity regarding its presence and consequence, even if its provenance - the how and why - remains darkly shrouded. We just know that to have been the most stupid thing ever done or said by anybody. Even our own stupidities, at first drowsily committed, seize us all too clearly in the disbelieving after-shock of self-revelation. This obscurity in media res expresses stupidity's (in its most aggravated and aggrieving forms) unforgiving incorrigibility. Unlike ignorance, error, or negligence, where, even in the most egregious of instances, some hope may prevail, stupidity seems to be impervious to reason, evidence, judgment, or any other instructable conscientiousness. Even the gods struggle in vain to trump stupidity, as Schiller remarks, for stupidity is that hand which trumps all hands of redemption and noble elevation. ${ }^{1}$ This constitutive incorrigibility of stupidity is

\footnotetext{
1 “Mit der Dummheit kämpfen Götterselbst vergebens" from his play The Maid of Orleans.
} 
all the more aggressive, the more it announces and celebrates itself as stupendously smart while gliding down the grand escalator of its own self-oblivious idiocy. Is there something unforgivable about the sheerness of stupidity or something eminently forgivable?

Stupidities, great and small, would seem to be what makes us human, all too human, in both despair and glory. A flawless human being without any disposition for stupidity would be roundly nonhuman. Even the gods on occasion do stupid things. Without the absent-mindedness of Epimetheus, human beings would never have been created as the existential lack of being which gives them so much power and ingenuity - thanks, of course, to his obliging brother Prometheus. Within the pantheon of the Greek gods, there is a god reserved for dispensing foolishness, fleetingly mentioned by Aristophanes, known as кoó $\lambda \varepsilon \mu o \varsigma^{2}{ }^{2}$ The Norse deity Hœnir is yet another deity who mishandled his critical role at the beginning of humankind. In assisting the thunderous Odin with the task of creating humans, Hœnir did something daft: he gave reason to these new creatures, yet in so doing left his own reason behind and thus became incapable of making any decisions himself (even as he had been elected chieftain). ${ }^{3}$ In this useless state, having been exchanged to another group of gods (the Vanir), when these discovered his dimwittedness, they promptly sent him back to his own Aesir tribe of gods, but not without having first beheaded poor Mimir, on whom he had relied to make decisions - all of this according to the Ancient chronicler Snorri Sturluson. ${ }^{4}$

Even the God himself might be implicated. In forbidding Adam and Eve to eat from the Tree of Knowledge, he surely must have known that the most efficient way to incite the transgression of what thou shall not touch is to loudly forbid it and place such forbidden fruit dangling there for all to see. As José Saramago plausibly writes in his novel Cain, the God, also known as Lord, can be faulted for at least two critical over-sights. As everyone knows, "being properly informed about something is always preferable to being ignorant" (Saramago, 2011, p. 4), and even though God in his wisdom commanded his elected creations not to partake of that fruit, such a blunt command was issued without any context or padding information. Our forbearers must surely have thought to themselves why? To which God's silence replied: it's the thing to do. On might wonder, on the one hand, whether the austerity of God's prohibition already signals what will become central in Kafka, namely, how senselessness - to be commanded full stop-becomes swathed in a mantle of mystery, and so easily comes to take on the quality of a metaphysical parable. ${ }^{5}$ On the other hand, this austerity of God's Law was reinforced by the obviousness of the tree's location; should God not have cleverly hidden the Tree of Knowledge, or just placed it somewhere else at a more discrete location within his bountiful garden?

\footnotetext{
${ }^{2}$ Aristophanes, Knights 221.

${ }^{3}$ Hoenir's gift is $\delta ð r$, an Old Norse word without English equivalent. $O \partial r$ is said to be the source of poetic inspiration, intellectual insight, spiritual ecstasy, and the legendary battle-frenzy of Norse warriors.

${ }^{4}$ For this account, see Daniel McCoy (2016).

${ }^{5}$ As Milan Kundera insightfully remarks: "In Kafka, stupidity is swathed in a mantle of mystery and takes on the quality of metaphysical parable. It intimidates. Joseph K. does his utmost to make some sense of its actions, its unintelligible words" (Kundera, 1988, p. 68).
} 
St. Aquinas would naturally object that God's wisdom is not just to know all possibilities, but to know all those possibilities that will become reality, as with his decision to plant the Tree of Knowledge in full view. But if so, would this not make God's infinite wisdom somewhat trivial, since even the most dim-witted among us can think themselves clever in orchestrating this feat of making a possibility real with such an obvious sleight of hand. You have discovered the egg you yourself have hidden, as the saying says. To be sure, we cannot know the veritable motivations that led to our ancestor's fateful bites, but even a venerable theologian, who openly admits at having no inkling of "what and how we chose" on that fateful day, grants that "it may have been, literally, greed - some silly thing like a fruit; our own experience shows us how often the greatest spiritual decisions depend on something almost almost equally trivial" (Williams, 2005, p. 122). Maybe it was not even greed or pride or desire, but something befitting creatures that were entirely ignorant of the distinction between Good and Evil, and thus who could not even be tempted by either. This lapsus in the forgetting of God's blunt prohibition points to the culprit of gullibility. We did not transgress God's Law for the sake of going against it nor because we were already animated by a desire to pass beyond any limits set before us. What tempted us? The stupidity of it all is that nothing tempted us in particular. We fell for being duped. Our innocence was lost in its own innocence as something like the flip-side of the tautological prohibition of God's law. Through a combination of lack of knowledge of Good and Evil and lack of critical self-awareness (and censure) in the eyes of the Other, we accepted the seducing words of the snake in innocence. We were neither wicked nor did we deceive ourselves. We were duped as easily as the Law we transgressed was delivered to us as that's just how it is.

After the serpent's ignoble sales-pitch and our acquiescence, God expels his cherished couple into the foreboding unknown of history and curses "the ground for your sake." God's curse weighs upon the entirety of his creation, as St. Paul reminds us, until its final redemption, but should we not wonder whether God is equally cursing himself sotto voce in his own disbelief at having done such a silly thing? We might equally wonder whether it is only because of this self-avowed disbelief that God comes fully into the grace, humility, and elected power of forgiveness for us humans. God must forgive himself so as forgive his children.

In this regard, Cioran rightly asks why we reached for the forbidden fruit in the first place rather than from the Tree of Life. At first, God did not place a prohibition from the Tree of Life, but does come to forbid it after the fact, once our ancestors realized, stupidly, that perhaps this should have been the tree from which they should have freely served themselves. "Then God said, 'Now, what if he (man) also reaches out his hand to take fruit from the tree of life, and eats of it and lives forever?' The Lord God therefore banished him from the garden of Eden" (Gen 3: 22-23). The impudence of this possibility would seem to have been the last straw. Why, however, did we chose (forbidden) knowledge over (available) immortality? Cioran suggests that the human was "unsatisfied with herself" for we are "only truly ourselves when, standing face to face with ourselves, we coincide with nothing, and not even with our own singularity" (Cioran, 1995, p. 1071). 
Abiding within this singular emptiness, the human "asked only to die" from an envy for God. As he elaborates: "wanting to equal his Creator by knowledge, not by immortality, he had no desire to approach the tree of life, was not at all interested in it" (Cioran, 1995, p. 1071). In this choice for mortality, the human wanted to attain the full sense of having been made in his Creator's image, for as Cioran argues, what we share with our Creator is an inaptitude for happiness. This inaptitude is manifest in our original infidelity to the gift of ignorance. To tweak, however, Cioran's insight: the human did not suffer from a Sartrean lack of being, as an existence that does not coincide with itself, but from the positivity of an indeterminateness or groundlessness, or what Deleuze calls stupidity (bêtise). This groundlessness of existence accounts for Adam and Eve's gullibility, such that their inaptitude for happiness (Cioran's valuable point) might better to said to reside along side with existential disposition for stupidity, in its most original form as the naiveté of listening (or, in God's case, speaking) without truly hearing what in fact is being said (and asked of us, or, as with speaking, told to others). This we have inherited not from Adam and Eve, but from God. In our fallen state, this groundlessness does not become abolished or suppressed. It becomes reconfigured into stupidity' intrigue, as the manifold ways in which the relation between our determinate individuation and our original indeterminate immaturity plays itself out.

As with this Biblical story of Eden and other mythological tales of humanity's creation, we originally owe something to stupidity. And even if human beings are said to be a useless passion, bereft of any gods or the God, our accidental being would thereby be all the more stupid given its lack of transcendent origin. How stupid must our existence be, once the question "why do we exist?" becomes deemed to be the most nonsensical of philosophical questions? As testified with the Eden affair, if it was through an act of stupidity (as it turns out, God's as well as ours) that we entered into humanity, it is likewise our enduring disposition for stupidity that distinguishes our maturity as human beings. Is stupidity that amplitude of maturity which makes us human, all too human?

\section{3. "Finally, my stupidity pays off!"}

Stupidity makes us human, stamps our maturity, much to our chagrin, and always at our own expense. By contrast, we would hesitate to consider with any stridency animals as able of stupidity, although numerous animals have been abducted into literary and mythological personifications for stupidity. In Aesop's Fables, we have a menagerie of foolish, stupid, and gullible animals as images for ourselves. The Ancient Greek comedian Archippus' play The Fishes stages a war between fish and the fish-loving-eating Athenians. A chorus of fish on the stage may even have been choreographed to dance. The comedian Lysippus tells us that the Athenians considered the donkey to be an especially stupid beast. By contrast, Aristotle proposes in his History of Animals that the inertness of sheep qualifies them for this honor. It is a slander that enjoys a venerable history from the Bible (p.s. we are the sheep) to the English language ("you muttonhead!") to George Washington's 
warning to this new yet unapproachable democracy ("If the freedom of speech is taken away then dumb and silent we may be led, like sheep to the slaughter") to its vindication in Robert Musil's "Sheep, As Seen in Another Light." As Musil contemplates:

As to the history of sheep: Today man views sheep as stupid. But God loved them. He repeatedly compared man with sheep. Is it possible that God was completely wrong? As to the psychology of sheep: The finely chiseled expression of exalted consciousness is not unlike the look of stupidity. (Musil, 1886/2006, p. 19)

At first glance, such an exalted consciousness of sheep would seem to mirror the blissfulness of Nietzsche's cattle. As he observes at the beginning of his essay "On the Uses and Disadvantages of History for Life": "Consider the cattle, grazing as they pass you by: they do not know what is meant by yesterday or today, they leap about, eat, rest [...] fettered to the moment [...]" (Nietzsche, 1874/1996, p. 60). Are these cattle happy, as the Polish philosopher Michalski wonders, simply because they're stupid? "Maybe their happiness is simply the flip side of their stupidity, the simple, undisturbed peace of the moment in which they live," which, we might add, returns always as the same, like the grass growing again with each renew spring (Michalski, 2007, p. 16). ${ }^{6}$ This exalted condition of Musil's sheep is somewhat more ambiguous, however, since as he concludes his reflections: "They [the sheep] don't seem to want to feel anything but the wind and the sun, and between their foreheads, the seconds striking out eternity that beats in their blood and signals from head to head like the hammering of prisoners on prison walls" (Musil, 1886/2006, p. 20). Is our own stupidity the failure to recognize that we, too, are dumb like sheep, and so remain obliviousness to being prisoners of our own stupidity, hammering on unseen prison walls? However we might want to adjudicate this philosophical disquisition (or inquisition?) on the stupidity of sheep and other like-minded beasts, thankfully, modern science has recently taken it upon itself to defend by methodological means and scientific seriousness the honor of sheep with the irrefutable discovery that "sheep might be dumb... but they're not stupid" (Townsend, 2005).

Just as imputing stupidity to animals might be seen as either betraying our own dimwittedness or conceit, or abducting them once again into the narrow-mindedness of anthropomorphism, so it would be strange to accuse an infant or child of being stupid. Even if

\footnotetext{
${ }^{6}$ The cow is dumb to his own stupidity, whereas we humans, as Nietzsche never tired of uncovering, succumb to more subtle form of stupidities, masked and sustained by our own conscious self-conceits. As Nietzsche writes: "Die Tugend ist unter Umständen bloß eine ehrwürdige Form der Dummheit: wer dürfte ihr darum übelwollen? Und diese Art Tugend ist auch heute noch nicht überlebt. Eine Art von wackerer Bauern-Einfalt, welche aber in allen Ständen möglich ist und der man nicht anders als mit Verehrung und Lächeln zu begegnen hat, glaubt auch heute noch, daß Alles in guten Händen ist, nämlich in der »Hand Gottes«: und wenn sie diesen Satz mit jener bescheidenen Sicherheit aufrecht erhalten, wie als ob sie sagten, daß zwei mal zwei vier ist, so werden wir Andern uns hüten, zu widersprechen. Wozu diese reine Thorheit trüben? Wozu sie mit unseren Sorgen in Hinsicht auf Mensch, Volk, Ziel, Zukunft verdüstern? Und wollten wir es, wir könnten es nicht. Sie spiegeln ihre eigne ehrwürdige Dummheit und Güte in die Dinge hinein (bei ihnen lebt ja der alte Gott, deus myops noch!); wir Andern - wir sehen etwas Anderes in die Dinge hinein: unsre Räthsel-Natur, unsre Widersprüche, unsre tiefere, schmerzlichere, argwöhnischere Weisheit” (Nietzsche, 1888, p. 268).
} 
we are born dumb to speech, we do not enter this world kitted with stupidity. At what age does a child mature into the aptitude of stupidity? When is a child no longer just charmingly and innocently silly, but annoyingly and despairingly stupid? Would this tipping point not mark that fateful moment when one is no longer just a child? How does one learn to be stupid? In adult life, to be childlike is manifestly different than being childish; the childish person can be stupid in ways that a childlike person cannot. While a child can neither be childlike or childish, what divides the childlike from the childish is what the child essentially lacks: the aptitude for pretension that only maturity affords.

There is evidently much pretense in a child's play, yet there is arguably no corrosive dose of pretension that would undermine the charm of make-believe for the sake of having or wanting to believe at all costs, that is, all too seriously. Proust, himself something of a forever child, who looked upon the adult world as a web of indecipherable signs, a forest of symbols, was essentially right when he observes that pretention is very close to stupidity. But if lack of pretention immunizes (in part, and only temporarily, since we must all grow up) the child from stupidity, it is conversely the concerted effort to mold the child into a respectable adult that generates the child's aptitude for stupidity and talent for pretension. Forced to abide by rules for which no adult can provide any creditable justification, regulated by norms that are clearly meant for everyone else but the child, incessantly told to be this, to do that, and generally coerced to conform to images and ideals, a child is coerced into a maturity we have already structured for her, and hence, earned for her, for our sake. This manufactured maturity stupefies the child: stupidity becomes the child in her acting-out against the force of law, compelled adoption of the commonplace, and society's violent breeding. As Adorno and Horkheimer remark: "The child's endless questions are already a sign of a secret pain, a serious question to which it has found no answer and which it cannot frame in its proper form" (Horkheimer \& Adorno, 1944/2002, p. 216). Stupidity is a scar, in their pithy and wise formulation.

A child can only survive to remain a child by playing the fool in a world of encroaching tragedy. In Seinfeld, that paean to the glories of immaturity, each of the charactersGeorge, Elaine, Jerry, and Kramer - are gifted with all sorts of inadequacies. Each stands in defiance against childhood unwillingly lost at the cost of being damned to eternal childishness. Through the litany of their gaffes, foolishness, dim-wittedness, selfishness, insouciance, and stupidities, they routinely expose the mindless mechanisms, asinine rules and regulations, hypocritical norms of political correctness, the commonplace ideas, and mythologies of everyday life. Society is the necessary conspiracy of organized stupidity masking itself as maturity, seriousness, and sophistication. Politeness is society's obliging accomplice. When George calls into question the sanctity of the prohibition against double dipping, when Jerry expresses his grief to Susan's parents at her tragic death with the words "she's not really dead if we find a way to remember her" - these and countless other instances interrupt the seamless naturalization of culture and social maintenance of stupidity. Why does double dipping provoke indignation worthy of the worst moral outrage? Why not plagiarize from The Wrath of Khan when needing to say something meaningful in a ritual defined by the impossibility of not saying what everyone else says, where, in 
other words, we're expected to say what must always be said, and hence plagiarize, in order to avoid coming-off as fairly stupid, as crassly unfeeling, or as idiotically having nothing to say, in not knowing what one should say on such a sad occasion.

Within those fields of being called the world, each character in Seinfeld exists with a fatal flaw, or $\dot{\alpha} \mu \alpha \rho \tau i ́ \alpha$, which time and again collapses any sustained surrender to pretense and the imaginary. Their respective forms of idiocy gives the lie to their own pretensions; the dimness of their imagination short-circuits any complete embrace of the imaginary; their childish illiteracy in social codes and signifiers grates any smooth captivation into symbolic order(s). In perpetually undermining attempts at maturity, they expose the pretensions of correctness, sophistication, and politeness that texture the social world and interpersonal relations. Seinfeld's satire unmasks the manifold pretentions of maturity, social as well as individual, with the figures of the fool, the child, the insane, and the man without qualities - the comedian - who aspires to none. A true comedian can never play, that is pretend, at the role of being a comedian, but must continually play in being a comedian. Neither in good faith nor in bad faith, his literalism arms his lack of qualities with disarming transparency. As Jerry declares in reaction to Whatley's encroachment on complete joke-immunity in the pretension of being a comedian:

JERRY: I have a suspicion that he's [Whatley] converted to Judaism purely for the jokes.

FATHER CURTIS: And this offends you as a Jewish person?

JERRY: No, it offends me as a comedian.

In Seinfeld's playgroup, we find figurations of stunted maturity, as various protests against maturity, from those who are nonetheless thrust into a world of maturity in which they cannot avoid coming-off as immature. Centered around the comings and goings through Jerry's apartment, there is neither exit nor refuge from the world of maturity. It is famously the show about nothing, there being no exit from nothing, as expressed in George's memorable pitch (a mise en abyme of the show about nothing within its own scene of nothingness):

GEORGE: I think I can sum up the show for you with one word: NOTHING.

RUSSELL: Nothing?

GEORGE: (Smiling) Nothing.

RUSSELL: (Unimpressed) What does that mean?

GEORGE: The show is about nothing.

JERRY: (To George) Well, it's not about nothing.

GEORGE: (To Jerry) No, it's about nothing.

JERRY: Well, maybe in philosophy. But, even nothing is something.

(Jerry and George glare at each other. The receptionist enters)

RECEPTIONIST: Mr. Dalrymple, your niece is on the phone. 
RUSSELL: I'll call back.

(Receptionist leaves)

GEORGE:(Attempting to spell his last name) D-A-L-R-I-M-P-E-L?

RUSSELL: (Obviously dislikes George) Not even close.

GEORGE: Is it with a "y”?

RUSSELL: No.

SUSAN: What's the premise?

JERRY: ..Well, as I was saying, I would play myself, and, as a comedian, living in New York, I have a friend, a neighbor, and an ex-girlfriend, which is all true.

GEORGE: Yeah, but nothing happens on the show. You see, it's just like life. You know, you eat, you go shopping, you read.. You eat, you read, You go shopping.

RUSSELL: You read? You read on the show?

JERRY: Well, I don't know about the reading.. We didn't discuss the reading.

RUSSELL: All right, tell me, tell me about the stories. What kind of stories?

GEORGE: Oh, no. No stories.

RUSSELL: No stories? So, what is it?

GEORGE: (Showing an example) What'd you do today?

RUSSELL: I got up and came to work.

GEORGE: There's a show. That's a show.

RUSSELL: (Confused) How is that a show?

JERRY: Well, uh, maybe something happens on the way to work.

GEORGE: No, no, no. Nothing happens.

JERRY: Well, something happens.

RUSSELL: Well, why am I watching it?

GEORGE: Because it's on TV.

RUSSELL: (Threatening) Not yet.

GEORGE: Okay, uh, look, if you want to just keep on doing the same old thing, then maybe this idea is not for you. I, for one, am not going to compromise my artistic integrity. And I'll tell you something else, this is the show and we're not going to change it. (To Jerry) Right? ${ }^{7}$

\footnotetext{
${ }^{7}$ http://www.seinfeldscripts.com/ThePitch.htm
} 


\section{Le Garçon}

Just over a century before, Flaubert crafted his own unstoried narrative of nothing happening with a pair of nobodies, copyists by trade, who, just like life, eat, amble here and there, and read. In his unfinished Bouvard and Pécuchet (a book which by definition could never attain completion), Flaubert acknowledged that he wanted "to produce such an impression of weariness and boredom that one might believe in reading the book that it had been written by an imbecile" (Flaubert, 1998, p. 647) With such encouragement from the author himself, why would we even bother to read such a self-avowed stupid performance of stupidity? Because it's in the library.

Bouvard and Pécuchet was conceived against "the bottomless abyss of stupidity" where accrued human knowledge would be represented "in a kind of encyclopedia made into a farce," as Flaubert writes in a letter. All things codified, transmitted, regulated, registered, listed, catalogued, and communicated becomes stamped into inanity through the manic collecting, collating, and comparing of Flaubert's nobodies. Flaubert claimed to have read 1,500 books for its composition, on subjects from the most esoteric to the most contemporary. As he declares in a letter, "the stupidity of my two characters has invaded me [...] their stupidity is my own and I am bursting with it" (Flaubert, 1998, p. 903). In this mindless "promenade in the infinite labyrinth of erudition" and "Tower of Babel of the sciences" (Guy de Maupassant's expressions), where human knowing becomes paraded in its inconclusive and contradictory profusion, Flaubert assaults the supreme form of maturity called Knowledge and its promised meaningfulness for life. ${ }^{8}$

La betise was a driving obsession of Flaubert's literary enterprise, reaching back to his first impulse to become a writer as a child. As the nine-year old Flaubert announces to his friend Ernest Chevalier: "There is a woman who visits father and who talks all sorts of stupidities, which I will write." This compulsion to expose in writing the stupidities of his surroundings (but also, his own) would germinate into a vast and unsparing exploration of human stupidity through-out Flaubert's novels, and which Milan Kundera considered one of the "greatest discovery of a century so proud of its scientific thought" (Kundera, 1988, p. 162). Progress, democracy, science, atheism, Christianity-nothing escapes Flaubert's indignation and literary parry.

In an evident echo of Flaubert's much quoted statement that "la bêtise consiste a vouloir conclure," Kundera notes that "the stupidity of people comes from having an answer for everything," whereas "the wisdom of the novel comes from having a question for everything." Yet, unlike a philosophical questioning armed with claims, counter-examples, and ideals, Flaubert's questioning is characterized by the absence of any authority and maturity for its venture. There is something of the blank stare in Flaubert's acute vision for stupidity. He remains too dumbfounded to respond with understanding or action, but reacts only with the act of writing, which, as with Bouvard and Pécuchet, becomes itself very nearly

\footnotetext{
${ }^{8}$ As Deleuze writes: "Let us for a moment be allowed to see Bouvard and Pécuchet as the outcome of the Discourse on Method" (1986, p. 276).
} 
the incarnation of the stupidity it exposes. As Flaubert remarks in a letter: "Je me sens démesurément stupide [...] Écrire, ne pas écrire. Publier est une idée recue." Without the ennobling outrage of Voltaire (and yet much appreciated by Flaubert, especially the parting wisdom of Candide: "Il faut cultiver notre jardin") or the humorless Weltschmerz of the elevated aesthete Steppenwolf, Flaubert's attitude towards stupidity is more akin to his acknowledged predecessors, Cervantes and Rabelais. ${ }^{9}$

In what Kundera calls the depreciated legacy of Cervantes, the origin of the modern novel discovers the life-world as an expanse of existential themes of human life ripe for literary investigation. As Kundera underlines Broch's idea of the novel: "The sole raison d'être of a novel is to discover what only the novel can discover" (Kundera 1988, p. 6). What is Cervantes' discovery? For Kundera, it is nothing less than the modern world as a problem:

As God slowly departed from the seat whence he had directed the universe and its order of values, distinguished good from evil, and endowed each thing with meaning, Don Quixote set forth from his house into a world he could no longer recognize. [...] Thus was born the world of the Modern Era, and with it the novel, the image and model of that world. (1988, p. 6)

This discovery of the modern world is inseparable from its discovery as the problem of stupidity. For Friedrich Schlegel, "the truly divine aspect" of Cervantes' novel is essentially shaped from the clay of foolishness (Narrheit) and stupidity (Dummheit). Both elements are mixed together in Don Quixote as well as Sancho Panza. Each is foolish and stupid, yet not in the same measure and degree. What distinguishes the foolish from the stupid, however, is a difference in education, or Bildung. While the foolish person is deemed a "scholastic" (Scholastik), the stupid person is dubbed "a man of the world" (Weltmensch). The former produces a certain naïveté through (over)sophistication (or Überstudiert, in Wieland's fine term from Die Geschichte der Abderiten); the latter proclaims a certain naïveté to be uncommon cleverness. As Schlegel remarks in his novel Lucinde: "A stupid person is one who does not believe what he sees. A fool is willfully stupid, and does not believe that he is; he is stupid out of artfulness." In the adventures of this Odd Couple, Don Quixote forms a parody of two intersecting genres: the Knightly Quest and the Philosophical Search. According to Schlegel's brilliant insight, the dialogues between Don Quixote (teacher/master) and Sancho Panza (student/apprentice) enact a parody of Socratic maieutic discourse. This parody of philosophical instruction is woven into a parody of Chivalry such that, taken together, this double-parody gives the lie to the search for sentimental education and wisdom, as well as the quest for Romantic transcendence (for this analysis, see Schmidt, 2011).

In a sketch for an envisioned work in his notebooks called "Sancho's Descent into Hell" (Sanchos Höllenfahrt), Schlegel imagined Sancho journeying into Hell as a narrative in which he could further explore three basic forms of idiocy: vulgarity (Plattheit), dumbness, or stupidity, (Dummheit), and foolishness (Narrheit). Sancho's descent into Hell in pursuit of his master, Don Quixote (who plays the part of Virgil for Sancho, the searching

\footnotetext{
${ }^{9}$ For the importance of Rabelais, see Culler (1974, pp. 162-164).
} 
poet), charts a course through cascading levels of idiocy, from the vulgarity associated with laziness and boredom, to worldly stupidities, to learned foolishness. In an allusion to Christ's calling, Sancho hears a voice: "Man enters eternal foolishness through me." This decent inverses the ladder of ascent from worldly ignorance to philosophical wisdom, for in a sketch for a final scene in Schlegel's never written arabesque, a symphony of university professors-philosophers? - would have appeared. As with Aristophanes in The Clouds, when stupidity (Dummheit) gains maturity, it becomes foolishness (Narrheit), "the loveliest and final origin of the truly amusing" (Polheim, 1966, p. 330).

Flaubert admired Don Quixote and attributed to Cervantes a critical impulse for his own literary endeavors. In one of the first reviews of Madame Bovary, the French literary critic Émile Montégut called attention to the affinities between Flaubert and Cervantes. As he remarks: "Just as Cervantes dealt the death-blow to the chivalric mania with the very weapons of chivalry, so with the very devices of the Romantic school Gustave Flaubert has demolished the false ideal that it brought into the world" (Montégut, 1876). Yet, it would be too limited of an optic to consider Madame Bovary solely from this angle, since it is not just the Romantic quest for transcendence that is "demolished," but as emphatically, that novel Romance of the $19^{\text {th }}$-century called Science and Family Romance bourgeois family. Although Madame Bovary is commonly read as a novel about the tragedy of its principle protagonist, Emma, it is inextricably a novel about the tragedy of Reason in the modern age, with the crucial difference that modernity's triumph is the tragedy, thus making its manifest destiny all the more comedic in a tragic sort of way.

\section{Ridiculus Sum}

In Madame Bovary, Flaubert interlaced a critique of modernity's pretension to maturity within the narrative of Emma's self-destructive desire for desire itself. According to Kant, the Enlightenment's declared emancipation from immaturity represented the realization of Reason's maturity (Mündigkeit). No longer a slave to the metaphysical drive for the unconditional, or Absolute, the modesty of Reason consists in mature self-examination and vigilant self-regulation. This $19^{\text {th }}$ century claim to maturity, and especially in Flaubert's post-Revolutionary context, the lauded virtues of positivism and Republicanism, is the centerpiece of Madame Bovary's critique of historical reason. Long before Adorno and Horkheimer, Flaubert penned his own dialectic of the Enlightenment in which emancipated and enlightened cleverness becomes diagnosed as the new stupid. When seen through Flaubert's lens, the Enlightenment appears as a grand project to either reform or eradicate completely human stupidity and its accompanying vices. What more noble endeavor could there be since the Fall of Humankind? On the other hand, what could be more foolish? For the Enlightenment, manifestations of stupidity (a judgment always leveled against the stupidity of others, the past, and other places that, by the by, is essentially gendered and Eurocentric) become targets of virulent critique: Christianity, Aristotelianism, Scholasticism, paganism, superstition, rural beliefs, mystical fanaticism, privileges of aristocracy, foolish pomp, cults, astrology, spiritual healing, etc. Liberty, equality, and 
fraternity are the watch-words for this desired world without stupidity, where reason alone would triumph in its political, social, psychological, and epistemological applications. Most significantly, the Enlightenment proclaims the sober abandonment of any foolish pretension to transcendence, other than the self-transformation of humankind in its historical maturity within the bounds of reason. Intolerance towards stupidity in the tribunal of Reason is obverse of the Enlightenment's optimistic self-image. The humility of Reason is not without fanaticism against all forms of unreason.

In Flaubert's France, within the encompassing circles of his own family (his father was chief surgeon in Rouen), social class (bourgeois: Gustave failed in his law studies, while his brother became a noted doctor), and culture (physiology, biology, and medicine were well developed in the early $19^{\text {th }}$-century), medicine enjoyed an elevated symbolic prestige and bio-political authority. Medicine was not only a theoretical and practical discipline. It became a social force through the implementation of public health policies and regulations, the increased moral standing of the doctor (displacing the local priest), and medicalization of French society. As Foucault examined in The Birth of the Clinic (as well as in his lectures at the Collège de France during the 1970s), medicine in France assumed social stewardship for the well-being of the body-politic. This transformation from the superstition and privilege of medicine in the Ancien Régime (a recurring theme in Molière's satirical plays) to the positivism and moral utilitarianism of Enlightenment medicine involved an epistemological transformation in how the medical profession was perceived and positioned, but equally with how the physician perceived persons and their bodies. The doctor's charge - his expertise in matters of physical health and mental wellbeing-became nothing less than the care of the modern soul.

Flaubert's choice in having Emma Bovary married to a provincial doctor is thus not accidental or merely a comment on his own social milieu. ${ }^{10}$ Madame Bovary opens with the introduction of the young Charles Bovary to a new classroom. With this launch, Flaubert delineates stupidity as a constellation of individuals, institutions, and things. There are stupid individuals, stupid statements and actions; there is collective stupidity, with its banalities, conformities and clichés; and there are stupid objects: the clothing that betrays our social pretenses, everyday trinkets and luxury items feeding our imaginary lives. Rather than identify stupidity with any particular quality or substance, stupidity is tracked through-out Madame Bovary in its plasticity, as taking different gestalts in an changing field suspended between three magnets: persons, institutions, objects.

In this opening scene, Charles Bovary walks onto the stage of Madame Bovary as an imbecile. He enters his new schoolroom as the country bumpkin with mismatched, ill-fitting clothes and sporting an absurd cap. His appearance is his being. His immediate failure to grasp the unwritten norms governing the classroom makes him into the class dunce. This

\footnotetext{
${ }^{10}$ The intelligent and sympathetic doctor Lariviere from Rouen, who arrives too late to save Emma from her poisoning, is often taken to portray Flaubert's own father.
} 
comedic portrayal of young Charles is, however, not without complexity. If his being stupid is symbolized with his clothing and ridiculous cap, he is just as much made to be stupid by social conventions and the coercions of conformity. As we are informed, students were in the habit of throwing their caps on the floor when returning to the classroom. Why? Because "it was the thing to do." As indicated by Flaubert's innovative use of italics, this custom remains without rhyme or reason, but nonetheless enjoys the force of law. Ignorant of such rules structuring this space of social intercourse, Charles, as the new kid, keeps his cap in his hands when, on this first day of class, returning to sit down. When then commanded by the teacher to stand up, who obviously finds this violation outrageous, his cap tumbles to the ground, much to the spontaneous derision of his classmates. Ordered to state his name aloud, Charles, desperately fumbling about for his cap, as if he had lost something essential about himself, stammers his name unintelligibly. The class erupts once more in boisterous, violent laughter. The teacher, ever more annoyed, punishes Charles by having him write out twenty times: ridiculus sum. With this act of repetitive writing "I am stupid," the circuit of constitution is complete in blurring the lines between being and being-made stupid.

The details are here everything. Charles" "composite cap" is described in all of its quirky incongruousness: lacking style and form, its "mute ugliness," as the narrator comments, "has a profundity of expression like the face of an imbecile" (Flaubert, 1857/1992, p. 4). He sports on his head the announcement of his own imbecile being; it cap provides a metonymy for his existence. Yet, it is very cap that poor Charles clutches onto for dear life. Faced with eviscerating laughter of Other, his only refuge is his stupid little cap; only with this object can he save himself from annihilation and hold himself together against the cruelty of others, the imperative of conformity, and the inviolability of the Law, whose only reason is that "it was the thing to do." In a Bergsonian key, his schoolmates' laughter functions as judgment, sanction, and self-preservation. Laughter testifies to a rupture in social cohesion, while restoring social cohesion. We laugh at the violation of norms that we know are necessary social intelligibility and regularity even as we know that such norms are arbitrary and without any deeply considered foundation. In our reaction of laughter, the threat to social norm is thrown-back onto the violator through shaming. Shamed before society (his classmates) and the authority of the Law (the school teacher), Charles is rendered speechless. He is made dumb: he cannot answer the demand to be a proper person (name), without stuttering his name and sounding utterly stupid.

In the midst of this disintegration of self, it is his precious cap that promises salvation, as the symbol of his own idiosyncratic uniqueness. It stands as a symbol for all those stupid little things to which we are attached in daily life, whose charm and significance is never known to others, and only dimly perceived by ourselves. We lack the intimacy of selfattachment were we not attached to these trifles and trinkets. We stutter to make ourselves known and heard; we stumble in our attempts to fit-in; we enter the world ill-fitted. Charles is stuck with being himself, with his imbecility, and must make due with himself. This cap allows him to make due with himself. Such silly attachments, as with Charles' clutching of his primary object, makes it that we can afford ourselves and hence make due with 
ourselves in a world for which we are maladjusted and ill-adapted. And yet, it is precisely such silly attachments, often remembered nostalgically as tokens of lost innocence, as with "Rosebud" in Citizen Kane, which are emblematic of our maladjustment to the world. Such objects, in their oddity and insignificance, contribute to our failed functioning in a teeming world of rules and regulations that suffer from their own brand of stupidity. Yet it is we, in our malfunctioning, who must doubly suffer for the stupidity on both sides of the coin: ours as well as society's.

We cannot gear ourselves into the world without a certain coefficient of grating. Much as with Monsieur Hulot and Kramer, Charles' physical awkwardness and fumbling manners are bodily manifestations of his existential maladroitness in a world not tailored and fitted for one's idiosyncrasies. However, comedic such physical gaffes are portrayed in this opening scene, they at the same time anticipate, more tragically, Charles' botched operation on Hippolyte's disfigured leg, when he allowed his gullibility (goaded by Homais) to get the better of his mediocre medical talents. Charles' evisceration under the force of the Law and of social derision is symbolized with the fall of his cap. Disrobed of his simpleton innocence, he becomes refitted by the very structure of this undoing: commanded to write twenty times "I am stupid," Charles becomes stupid in a different key, as materialized in this repetitive act of writing oneself a new form of existence. This transmutation from country-bumpkin to respectable student traces an arc from idiocy (Narrheit) to the learned stupidity of the modern world in its essential form: mediocrity, banality, and triviality, or a combination of Plattheit and Dummheit in Schlegel's term.

Despite his imbecility, he manages to become respectable in (just) passing his medical exams. He is not properly speaking a Doctor, but a Medical Officer. For a person who at first seemed a hopeless imbecile and, as the narrator tells us (who himself drops suddenly from view), was entirely unmemorable, Charles has nonetheless arrived. His success is living testimony to the open secret of mediocrity: as long as everyone else remains mediocre, anyone, however stupid, can succeed. Due to the resourceful scheming of his mother, he gets married; life seems to be settled. And then one night, he receives the message that a local farmer has broken his leg, in need of medical attention.

Due to a stroke of good fortune with his mending of the farmer's broken leg, he gains a local reputation as a "doctor" (even though, strictly speaking, he is a Medical Officer) and, more importantly, is given the occasion of meeting this farmer's daughter. With their first encounter, it is striking that Charles remains entirely blind and unresponsive to Emma's erotic allure. While he is tending to her father's leg, Emma sits discretely in the corner of the bedroom. She is sewing, yet is evidently not adept at this household task, for she keeps pricking herself and raising her finger to her mouth for a soothing suck. For us readers, as undoubtedly for any man other than Charles, this detail could be felt as tantalizing. It is not that Charles is not looking. In fact, we know that Charles is observing Emma from the corner of his eyes (and thus not really paying attention to his patient), since we are told that what Charles finds surprising about Emma is the whiteness of her fingernails, even as he tells himself that he does not find her hands beautiful at all. Through indirect discourse 
(a style of narration pioneered in Madame Bovary by Flaubert), we are told that "what was beautiful were her eyes," yet this statement reflects what everyone else would find beautiful about Emma, but precisely not Charles, who does not find her particularly beautiful. This scene suggests that Emma's gaze is searching for Charles' as she sits there sewing without success. Charles, however, is not there for her gaze to fall upon. He's absent mindedly trapped in his own gaze at her fingernails. Charles' unerotic nature is further confirmed as he leaves the farm, Les Bertaux. About to take his leave, he fumbles around in search of his riding crop. Emma happens to see it first, and reaches to grab it. Charles "gallantly" hurries to get it himself. As he stretches out his arm, "he felt his chest brush against the girl's back, stooping beneath him. She straightened up quite red in the face and looked at him over her shoulder, holding out his whip" (Flaubert, 1857/1992, p. 16).

Charles is smitten, even though he does not ask himself why, and even if he did, he would have conjured up some banal explanation. He returns to the farm to ostensibly check on the progress of his patient's healing and arrives during the late-afternoon while every one is in the fields. He enters the kitchen without noticing Emma. She is sewing, once again, and once again, he fails to notice her in her being. This scene is delicately painte in muted colors and with softly paced sentences, much as an image in Vermeer. She sits close to the hearth, next to a window with shutters closed. Beams of sunlight stream illuminate the room; all is quiet. Emma, who "wore no fichu," is simply present to her task, and not, as with her earlier episode of sewing, distracted: "on her bare shoulders you could see little drops of sweat." It is a lovely image with symbolic significance: lost in her domestic work, Emma sits poised between a shuttered window to something more, transcendence, and the hearth of being at home. Sunlight cascades into this scene from two points of entry: down the chimney bursting into colors on cinders; transversally through shuttered windows. Placed in the middle of Flaubert's painted tableau, and literally placed at the center of its written paragraph, another drama plays itself out quietly. It is sight unseen by Emma or Charles, as well as, most likely mostly, Flaubert's readers, "Flies, on the table, were crawling up the glasses left there, and buzzing about in the bottom, drowning in the cider dregs" (Flaubert, 1857/1992, p. 21). Pressed from celebrated Norman apples, which distantly recall once forbidden fruit, flies are drowning in the nectar of their own temptation, stuck fast to the sweetness of their desires.

In a brief text called "Flypaper," Musil once reflected on the spectacle of flies twisting and turning to extricate themselves from sticky paper. As flies succumb to fatigue and desperation, Musil perceives in the contortions of their bodies a metaphysical plight. In a final moment of collapse, something "appears totally human." As Musil describes:

Sometimes such a movement sweeps over the lot, then all of them sink a little deeper into death. And only on the side, near their legsockets, is there some tiny wriggling organ that still lives a long time. It opens and closes, you can't describe it without a magnifying glass, it looks like a miniscule human eye that ceaselessly opens and shuts. (1886/2006, p. 5) 
It is one of the most horrific images in modern literature, rivaling H. P. Lovecraft. What is here so human? As an allegory for how we become stuck fast to the stuff of our undoing (to adopt here Peter Wortsman's fine formulation), this scene of agony highlights how those attachments which imagine ourselves not being without, those things that we care for and give us meaning, is the very stuff of our undoing. All too frequently, stupidity feeds from and feeds what we desire most.

"What is your aim in philosophy?", Wittgenstein (1956/2009) asks in his Philosophical Investigations (\$309). "To show the fly the way out of the fly bottle." In his own way, Flaubert already anticipates the thought expressed here when he writes in his Dictionary of Received Ideas: "PHILOSOPHY: Always snicker at it." For Wittgenstein, philosophy often becomes trapped in problems of its own devising. The more we struggle to find a solution from these entrapments, the more, like Musil's flies, are we undone by the stuff of our own philosophical convictions. The philosophical quest, in this regard, resembles Don Quixote's adventures, as Schlegel noted. For Flaubert, the futility of philosophy reflects its Quixotic sense of mission in searching for an antidote or redemption for human stupidity. Reason becomes undone in being stuck fast to its dream. But as with the images of the flypaper and the fly-bottle, Stupidity is both the attachment (Charles' silly cap, the flypaper) and the attempted extrication from attachments (the flies in the bottle). Reason becomes stupid in its enlightenment project to extricate humanity from the stuff of its attachments, even as those attachments may very well be stupid to begin with.

There is subtle metaphysical meaning in Musil's allegory of flypaper that converges with the closing image of his meditations on the stupidity of sheep. Musil's sheep are not dumb like Nietzsche's cows. Although, in one sense, sheep exist within the cyclical eternity of nature, in another sense, the seconds ("which signal from head to head") that strike eternally in endless and meaningless repetition are the bleating sounds of "hammering of prisoners on prison walls" (Musil, 1886/2006, p. 20). As with Wittgenstein's fly-bottle, we are locked in a room, and even if we are oblivious to our confinement, like sheep or flies, we remain stuck in our attachments. Our lives are fated to either the boredom of cyclical repetition or futile escape from these cyclical motions. Whereas the sheep are dumb in not realizing the horror of their monotonous existence, the flies are dumb in not sensing that the only exit promising escape - transcendence - is that opening top of the bottle which their own nature prevents them from seeing.

\section{Gorgeous Pink-Feathered Bird}

Charles' wife is no fool. She immediately senses why he has such a smile on his face when he repeatedly goes to visit Les Bertaux. She forbids him to return anymore; he obeys. This prohibition gives him, so he feels, "the right to love" Emma. We oblige ourselves with the seal of resentment to have what we are told not to have. His wife soon dies, leaving the path open. But it does not beckon. For even after subsequent visits to the farm, nothing 
came to his mind about love, nothing of the mood for love, despite Emma's evident attractiveness. Try as he might, when he recalled her in his mind: "[he] never could imagine her, other than as he had first seen her, or exactly as he had just left her" (Flaubert, $1857 / 1992$, p. 22). Their first meeting repeats itself in his mind, like the drone of an anonymous voice telling him that he should get married. As we are told: "But the image of Emma kept coming back to him, kept appearing before his eyes, and there was something monotonous like the noise of a humming-top droning in his ears: 'The doctor wants a wife, he does! The doctor wants a wife!'” This repetition, as the scar of his trauma in writing twenty-times "I am stupid," over-writes any genuine desire. The voice he hears within is the voice of social propriety - that every doctor must have a lovely wife — which tells him to marry and thus attain the pitch perfect image of a respectable country doctor. He gets married since it is the thing to do.

If the decision to marry his first wife was entirely his mother's doing, his decision to ask for Emma's hand was never a decision he made with any resolve or passion. He did not fall in love with her. Love befell him, as fortuitously as the circumstances of having been called upon to mend a simple broken leg. And yet, in spite of this lack of passion, once Charles finds himself married to Emma, he plays the role of husband perfectly. There is an honest happiness to his new conjugal arrangement. Charles's existence is defined by a settled sense of being at home, satisfaction of material pleasures, and the embrace of domestic routine. As Flaubert remarks in a letter: "Être stupide, égoïste et avoir une bonne santé sont les trois conditions du bonheur, mais si la stupidité n'est pas là, tout est perdu." His life becomes cyclical in nature, always returning to the same point of departure: to his home and beloved wife. This assuredness of home and hearth permeates the fabric of everyday life and is figuratively woven into the threads of Emma's clothing: "the universe, for him, did not extend beyond the silken round of her skirts." Charles' happiness perpetually circles around his earthly needs; one does not hear the hammering of a prisoner in search of escape. At most, there is the passing whiff of a fragrant beyond, to which Charles remains insensitive and unmoved.

He ate omelettes on farmhouse tables, thrust his hand down into damp beds, had his face splashed with warm-spurting blood, listened to many a death-rattle, examined the contents of chamber-pots, unbuttoned plenty of grubby under-linen; but he found his way, every evening, to a blazing fire, a meal, a comfortable chair, and an elegant woman, delectable and fragrant, with a quite mysterious perfume, from her skin perhaps, scenting her skirts.

Charles' happy simple-mindedness contrasts with Emma's longing for transcendence and deliverance. Her agitation sets-in immediately after their marriage is sealed: "down in her soul, she was waiting for something to happen. Like a shipwrecked sailor, she perused her solitary world with hopeless eyes, searching for some white sail far away where the horizon turns to mist." A profound absence defines her existence. It is an absence that becomes drawn out, pronounced, and set into motion in the presence of Charles' banality of nothingness. As she acutely senses: "this man knew nothing, taught nothing, desired nothing. He thought her happy; and she resented his so-solid calm, his ponderous serenity, the very 
happiness that she brought him" (Flaubert, 1857/1992, p. 32). Emma's existential intelligence recognizes that she constitutionally could never accept that kind of happiness that gives his nothingness a sense of fullness. Charles is doubly dumb: he is dumb to her predicament, in her need for something more than happiness, and he is dumb to his own nothingness - his existence, in which we thinks to have found serenity and contentment. While the nothingness of Charles is flat, the nothingness within Emma is profound. Her violent resentment against her husband represents a metaphysical rejection of the gift of ignorance. Emma experiences neither fulfillment nor happiness (their first conjugal night leaves her untransformed while Charles' becomes the dotting husband) in her domestic life.

Marriage exposes an essential absence, the depth of which is measured by a disparity between an idea of love and the reality of its absence. What crystallizes in her soul is the desire for desire itself in her longing "to find out exactly what was meant in real life by the words felicity, passion and rapture, which had seemed so fine on the pages of the books." Her imagination becomes bewitched by images from novels of adventure and love, stories of exotic lands, scandalous erotic narratives, histories of mistresses, kings, and "illustrious or ill-fated women," and fantasies of Ancient kingdoms. Her reveries attain the heights of a soaring image, verging on kitsch, that finally captivates her into believing that she has now attained the the truth of her desire: "she at last possessed that marvelous passion which had hitherto been like a gorgeous pink-feathered bird floating high above in a splendid poetical heaven."11

Emma's revolt against her husband's banality of happiness and the mediocrity of the world spurs with a vengeance her longing for transcendence, for there being more to life than life, high above in some kind of sublime heaven. In this desire for the Romance of transcendence, we hear a distant echo of Emma's aborted religious vocation before her unhappy marriage. As a young girl, she was sent to receive an education in the care of nuns at a convent. At first, she proved receptive to religious teachings and spiritual life, but soon came to be enamored instead with the "church for its flowers, music for the words of its songs, and literature for its power to stir passions" (Flaubert, 1857/1992, p. 36). Her spirit "rebelled before the mysteries of faith," which proved antipathetic to her nature. She eventually leaves the convent to return to her father's farm. With this portrait of Emma's turning away from the love of God, Flaubert cleverly depicts Emma's waywardness from Christianity in terms that refer implicitly to Aquinas' notion of stultitia in the Summa Theologiae. Aquinas distinguishes between stultitia (stupidity) and fatuitas (idiocy): whereas the latter does not stand in opposition to wisdom given its absence of spiritual sense and judgment, the former is opposed to wisdom due to its blunted judgment and wayward spirit. Stupidity can be a sin, as Aquinas considers, if a person deliberately - as with the case of Emma - turns her regard away from God towards earthly things: the candles and flowers of mass rather than its spirit. As Aquinas writes, stupidity is the "dullness of perception in judging, particularly about the Highest Cause, the Last End and Sovereign Good." When due to natural conditions, stupidity is not a sin; when arising from "burying

\footnotetext{
${ }^{11}$ For the functioning of the imagination in the constitution and conspiracy of Emma's desire, see de Warren (2018).
} 
his mind so deep in earthly things as to render his perceptions unfit to grasp the things of God and Spirit of God," then stupidity is sinful. As he continues: "Though no one wishes to be stupid, still people do wish for what leads to stupidity, by withdrawing their thoughts from things spiritual and burying them in things of earth."

Aquinas must have known a thing or two about stupidity, since he was considered somewhat dumb (as was Flaubert in his youth) as a student by his teachers and classmates. His was even given the name of the Dumb Ox. In G. K. Chesterton's memorable description: "St. Thomas was a huge heavy bull of a man, fat and slow and quiet [...] so stolid that the scholars, in the schools which he attended regularly, thought he was a dunce. Indeed, he was the sort of schoolboy, not unknown, who would much rather be thought a dunce than have his own dreams invaded, by more active or animated dunces" (Chesterton, 2014, p. 3). ${ }^{12}$ Nevertheless, Aquinas' notion of stupidity reaches back to an accusation of stupidity leveled against all those who are deaf and dumb to God's divine revelation. As it is written in the Book of Wisdom (13: 1): "Yes, naturally stupid are all men who have not known God and who, from the good things that are seen, have not been able to discover Him-who-is, or, by studying the works, have failed to recognize the Artificer." In this passage from the Old Testament, the stupid are identified with the idol-worshipping Egyptians in contrast to the wisdom of the Israelites. With his decision transvaluation of this Biblical demarcation between the stupid and the wise, St. Paul proclaims that "what God makes plain in his creation, as his creation, is written in the hearts of men" (Romans 1: 19). The Law of God is inscribed in humankind (Romans 2: 14); those too stupid to accept God are those who have not passed to the maturity of embracing Christ and discovering what is there plain to see. Stupidity defines both atheism and paganism. Christian wisdom, however, even as its stands opposed to stultitia, cannot be enjoyed without the cultivation of a certain foolishness, for we are, as St. Paul writes to his Christian brethren, "fools for Christ's sake. (Corinthians 4: 9-10). Less we be stupid in our own pretension to wisdom: "Let no man deceive himself. If any man among you seemeth to be wise in this world, let him become a fool, that he may be wise. For the wisdom of this world is foolishness with God. For it is written, He taketh the wise in their own craftiness" (Corinthians 3: 18-19).

Faithless to Christianity and unfaithful to her husband, stupid from the perspective of Christianity and foolish from the perspective of the world in which there is no longer any place for transcendence, Emma's pursuit of her "splendid poetical heaven" leads her into the arms of two lovers with self-destructive consequences. Although foolish in love and godless in her stupidity, Emma is, however, no fool: she recognizes, much to her disgust, the banality of her husband's happiness and childish love much as she perceives the pretensions and falsities of those around her. Her flight to the imaginary in pursuit of the "pink-feathered bird," however absurd, is nonetheless truthful to the central problem posed by Flaubert through her character. There is profundity to Emma's betise. Of the all the

\footnotetext{
${ }^{12}$ The Aquinas scholar Jean-Pierre Torrell cautions that to be called a dumb ox (a title given to Aquinas by his teacher Albert Magnus) was at the time not as pejorative as it might sound for us today. Maybe; then again, who would ever want to be called both dumb and an Ox?
} 
characters in the novel, Emma possesses the exceptional virtue of realizing that something is profoundly missing in her life. Whereas the pharmacist Homais represents the self-assuredness of Enlightenment cleverness, Charles the dimwittedness necessary to remain happy without any aspiration, and the priest Bournisien a Christianity eclipsed — each a different form of stupidity, Emma knows that stupidity, mediocrity, and conformity reign over the world. Her melancholy is contemplative. Her disgust at the banality of her husband's way of being reflects her awareness of the idea of received ideas. Unlike the characteristic cowardice of the males in her world (including her two lovers), Emma's daring is to experience the Real of desire.

Emma incarnates an impossible choice. We can either accept to be stupidly happy in our provincial ways without any need for something more than life; or we can fool ourselves into a maturity that masks its own hypocrisy, narrowness, and superficial cleverness; we can, as with Emma, despair of the folly of the world and chase after a transcendence in a world without place or need for something more than life. Indignation at stupidity coupled with a rejection of the wisdom of the world leads to a foolishness, in the absence of God, for nothing. ${ }^{13}$

\section{Funeral Oration}

"After a person dies, a sort of stupefaction settles in, always, so difficult is it to comprehend this sudden advent of nothingness and to resign oneself to believing it." With this description, the final scene of Emma's fateful life, her lying in wake after her suicide by arsenic poisoning, begins. Of all those who witness and must bear the significance of her death, of all those who have accompanied her along her destiny, Emma proves to be the only one who, in a last convulsion before expiring, breaks through the veil of stupidity governing the world. Just as her life is about slip away entirely, she becomes suddenly seized and sits up "like a corpse galvanized" with eyes wide open (symbolically and literally) as she hears a vagabond blind man's song outside her window. She emits "a horrible, frantic, despairing laugh," and collapses in convulsion into the "darkness of eternity" (Flaubert, 1857/1992, p. 305). There is Nietzschean amor fati in his terrible laughter at the dark. In spite of it all, realizing her own foolishness, she affirms the destiny that she only has prescribed to herself. In this enigmatic blind wanderer - a figure harkening back to a time before the advent of Modernity — we might see God's vengeful angel, who comes to punish the stupidity of those whose spirit rebelled against God, and yet whose stupidity touched on the Real of a transcendence without God. Is God's joke on us? Is Emma's laughter in fact God's? To have withdrawn from the world and yet struck Emma down from afar, so as to allow our own hubris of Enlightenment to triumph as the maturity of

\footnotetext{
${ }^{13}$ When Flaubert declared "Madame Bovary, c'est moi," he might have meant that it was only through his writing of Madame Bovary that he could transubstantiate the Emma in him into the writer Gustav. Writing would thus be an exorcism of his own stupidity. Through writing, Flaubert transforms his indignation at the stupidity of the world and rejection of banalities by transforming that dream of splendid poetical heaven into the splendid work of the imaginary called literature.
} 
stupidity which we moderns most deserve? Might this be what Flaubert meant when he spoke of "the secret Jansenism" of his novel? (Thibaudet, 1982, p. 109).

But even with death, the symphony of stupidity continues to be played. Bereaved beyond consolation, Charles throws himself on Emma's corpse in tears of grief over the death of his wife. Even as he was betrayed by her affairs, duped by her deceit, ruined financially by her extravagant and desperate spending, and forced to abandon their daughter to the fate of so many children in the glorious $19^{\text {th }}$-century of capitalism (the last we hear of her, she is working in a cotton mill), Charles remains faithful to his naive sense of love. Predictably, Homais responds with a banality verging on insensitivity: "weep, let nature take its course. It will bring you relief!" In Homais' universe, there is not tragedy, only progress. It is a statement made all the more crass given his own opportunistic composition of an article about Emma's demise for a local newspaper. Charles' childish love does not abandon him. He requests to have his beloved "buried in her wedding dress, with white shoes on, and a wreath [...] hair spread over her shoulders." Even in death, as in life, he cannot truly see her for who she was or needed or wanted to be; but now, given her death, why should he? In this moment of grief, to want to see the truth of those whom we mourn would itself be foolish, destroying as it would the sanctity of the dead, even at the expense of a necessary and illusionary sentimentality. If anything, it is truth of the dead that cannot be spoken or acknowledged in the hour of their death. Charles' immaturity is once more on display when, in reaction to a clergyman's discourse about the vanity of earthly things and God's wisdom, he bursts out: "I loathe him-your God," to which the clergyman responds with knowing condescension, as one would speak to a petulant child: "The spirit of rebellion is still in you" (Flaubert, 1857/1992, p. 307). As with his opposite Homais, there is no tragedy in the universe of the priest, but only elevation in death.

The pharmacist Homais and the curé Bournisien, each caretakers of the soul, sit vigil that evening over Emma's body. Homais, ever the pedant, has brought with him a few books and a notebook in order to take scientific notes. Bournisien sits there quietly to the flicker of candlelight. Silence, however, can be oppressive for a maturity (Mündigkeit) that always feels compelled to speak one's mind freely, regardless of circumstance and ritual. Breaking this respect of silence, Homais launches a debate with the obliging Bournisien regarding the truth or falsity of Christianity. In heated back and forth, the respective avatars of Faith and Reason each appeals to an alternative cannon of texts: read Voltaire and d'Holbach, shouts one; read the Letters of Some Portuguese Jews and Proof of Christianity shouts the other. Even in death, Emma is caught between an eclipsed Religion and a presumptive Science. Each stands blind to the irony of existence, that death undermines all human pretense and pretentions - a death that only Emma, in her foolishness, embraced, as the last laugh she has on them. These "two deadly agélastes," in Kundera's words, "go on endlessly trading their inanities like a kind of funeral oration" (Kundera, 1988, p. 162). The term used here by Kundera, agélaste, is of Rabelais' coinage. A neologism formed from Greek, the agélaste is the person who does not laugh and who lacks any sense of humor. Beneath this exchange of inanities in this funeral oration for stupidity-Emma'sthere lurks a darker source of stupidity: power. Homais and Bournisien each represents 
the same phenomenon of how power makes stupid. As Nietzsche observes, "politics devours all seriousness for really intellectual things," such that the greater the power, the greater the decline of rationality and embrace of stupidity. "Power makes stupid" (Nietzsche, 1895/2014) as he writes in Twilight of Idols. For Nietzsche, power permits stupidity in divesting itself from the value of thinking. The greatest manifestation of power is the power to decide and impose what counts as "intelligent" and "stupid." As Nietzsche states his fundamental insight in Beyond Good and Evil:

O sancta simplicitas! What a strange simplification and falsification people live in! The wonders never cease, for those who devote their eyes to such wondering. How we have made everything around us so bright and easy and free and simple! How we have given our senses a carte blanche for everything superficial, given our thoughts a divine craving for high-spirited leaps and false inferences! - How we have known from the start to hold on to our ignorance in order to enjoy a barely comprehensible freedom, thoughtlessness, recklessness, bravery, and joy in life; to delight in life itself! And, until now, science could arise only on this solidified, granite foundation of ignorance, the will to know rising up on the foundation of a much more powerful will, the will to not know, to uncertainty, to untruth! Not as its opposite, but rather - as its refinement! (Nietzsche, 1886/2002, p. 25)

All the while, Emma's corpse is there: "the corner of her mouth, which was open, made a sort of black hole in the lower part of her face [...] the sheets sagged from her breasts to her knees [...] and it seemed to Charles that an infinite mass, an enormous weight, was pressing down on her" (Flaubert, 1857/1992, p. 308). That enormous mass, which only Charles, in its stupefaction, can see, is the mass of nothingness that presses against us all, which no amount of faith or reason or power can alleviate, regardless how stupid or inane. In the presence of this nothingness, two regimes of stupidity, each accusing the other of stupidity, and insensitive to the death just beneath their eyes, play out their farcical combat against dragons each the other cannot see as the other's windmills.

Charles will soon thereafter die suddenly; the doctor, with this expert medical gaze, "opened him and found nothing." He literally died from nothing, from her death. His destitute child will fall into the historical oblivion of working in a cotton mill. From this destruction, Homais emerges triumphant. As the exemplification of the modern homo faber, whose cleverness is worldly in being entirely practical and without any sense or acceptance for tragedy or transcendence, Homais' stupidity is positive, technical, and opportunistic. As reported in the closing words of the novel, "he has just been awarded the cross of the Legion of Honor." Stupidity has awarded itself its highest honor: another stupid medal. Madame Bovary still thankfully remains in the library.

\section{References}

Alfvaen. (1992). Expressions for stupidity. Retrieved September 1, 2018 from https://groups.google.com/forum/\#!topic/rec.humor/oIJNt3z3CzE

Cioran, E. (1995). La chute dans le temps. Paris, France: Gallimard. 
de Warren, N. (2018). Imaginations of Stupidity. Jules de Gaultier, Flaubert and Le Bovarysme. In D. Nikulin \& S. Geniusas (Eds.), Productive Imagination: Its History, Meaning and Significance. London, UK: Routledge.

Deleuze, G. (1968). Difference and Repetition. (P. Patton, Trans.). New York, NY: Columbia University Press.

Flaubert, G. (1973). Correspondance (Vol. II). Paris, France: La Pléiade.

Flaubert, G. (1992). Madame Bovary. (G. Wall, Trans.). London, UK: Penguin. (Original work published 1857)

Flaubert, G. (1998). Correspondance (Vol. IV). Paris, France: La Pléiade.

Heins, A. (1957). Die Ausdrücke zur Bezeichnung der Dummheit im Französischen: Zur Einwirkung des Affekts auf die Entwicklung des Wortschatzes. Berlin, Germany: Humboldt University.

Horkheimer, M., \& Adorno, T. (2002). Dialectic of Englightenment. (E. Jephcott, Trans.). Stanford, CA: Stanford University Press. (Original work published 1944)

Kundera, M. (1988). The Art of the Novel. (L. Ahser, Trans.). New York, NY: Grove Press. (Original work published 1986)

McCoy, D. (2016). The Viking Spirit. An Introduction to Norse Mythology and Religion. North Charleston, SC: CreateSpace Independent Publishing Platform.

Michalski, K. (2007). The Flame of Eternity: An Interpretation of Nietzsche's Thought. Princeton, NJ: Princeton University Press.

Montégut, É. (1876). Les nouveaux romanciers. In É. Montégut, Revue de deux mondes.

Musil, R. (1990). On Stupidity. In B. Pike \& D. Luft (Eds.), Precision and Soul. Chicago, IL: University of Chicago Press.

Musil, R. (2006). Posthumous Papers of a Living Author. (P. Wortsman, Trans.). New York, NY: Archipelago Books. (Original work published 1886)

Nietzsche F. (2014). Twilight of idols. (W. Kaufmann \& R. J. Hollingdale, Trans.). Luxembourg: CreateSpace Independent Publishers. (Original work published 1895)

Nietzsche, F. (1997). On the Uses and Disadvantages of History for Life. (R. J. Hollingdale, Trans.). In D. Breazeale (Eds.), Untimely Meditations (pp. 57-124). Cambridge, UK: University Cambridge Press. (Original work published 1874)

Nietzsche, F. (2002). Beyond Good and Evil. (J. Norman, Trans.). Cambridge, UK: Cambridge University Press. (Original work published 1886)

Polheim K. (1966). Die Arabeske. Ansichten and Ideen aus Friedrich Schlegels Poetik. Paderborn, Germany: Ferdinand Schöningh.

Saramago, J. (2011). Cain. (M. J. Costa, Trans.). Boston, NY: Houghton Mifflin Harcourt. (Original work published 2009)

Schmidt, R. (2011). Forms of Modernity: Don Quixote and Modern Theories of the Novel. Toronto, ON: University of Toronto Press. Retrieved September 25, 2018 from http://www.jstor.org/stable/10.3138/j.ctt2ttp13 
Thibaudet, A. (1982). Gustave Flaubert. Paris, France: Gallimard.

Townsend, M. (2005, March 6). Sheep might be dumb ... but they're not stupid. The Guardian. Retrieved September 25, 2018 from https://www.theguardian.com/uk/2005/mar/06/science.animalwelfare

von Schlegel, F. (1963). Friedrich Schlegel: Kritische Ausgabe seiner Werke. Paderborn, Germany: Ferdinand Schöningh.

Williams, C. (2005). He Came Down From Heaven. Berkeley, CA: The Apocryphile Press.

Wittgenstein, L. (2009). Philosophical Investigations. (G. E. Anscombe, Trans.). London, UK: Wiley-Blackwell. (Original work published 1956) 